\title{
QUEEN'S
UNIVERSITY
BELFAST
}

\section{Amnesty and International Law}

Mallinder, L. (2018). Amnesty and International Law. Oxford Bibliographies.

https://doi.org/10.1093/OBO/9780199796953-0172

\section{Published in:}

Oxford Bibliographies

\section{Document Version:}

Peer reviewed version

Queen's University Belfast - Research Portal:

Link to publication record in Queen's University Belfast Research Portal

\section{Publisher rights}

(C) Oxford University Press 2018. This work is made available online in accordance with the publisher's policies. Please refer to any applicable terms of use of the publisher.

\section{General rights}

Copyright for the publications made accessible via the Queen's University Belfast Research Portal is retained by the author(s) and / or other copyright owners and it is a condition of accessing these publications that users recognise and abide by the legal requirements associated with these rights.

Take down policy

The Research Portal is Queen's institutional repository that provides access to Queen's research output. Every effort has been made to ensure that content in the Research Portal does not infringe any person's rights, or applicable UK laws. If you discover content in the Research Portal that you believe breaches copyright or violates any law, please contact openaccess@qub.ac.uk. 
Amnesty and International Law

Louise Mallinder

Introduction

General Overviews

Monographs

Articles, Book Chapters, and Guidelines

History of the Use of Amnesties and the Growth of the Anti-Impunity Campaign

Sources Regulating the Use of Amnesty

Treaty-Based Prosecution Obligations

Customary International Law

International Human Rights Law

The Extraterritorial Effects of National Amnesties for International Crimes

Amnesties in the Case Law of the Hybrid Courts and the International Criminal Tribunal for the Former Yugoslavia

Amnesties and the International Criminal Court

Amnesties and Prosecutions in Third States

Conditional Amnesties and Non-Judicial Remedies

\section{Introduction}

International law has no agreed definition of amnesty, largely because state practice on defining and using amnesties differs enormously. Amnesty, as understood in this article, refers to measures adopted by states to release categories of individuals or offences from criminal liability. States adopt amnesties for different purposes depending on context. These purposes can be both positive and negative. Amnesties can remedy human rights violations by releasing those who have been arbitrarily detained or removing obstacles to refugees returning home. In contrast, amnesties can create impunity for perpetrators of international crimes and gross human rights violations. Most commonly, they are enacted to facilitate political transitions and, in post-conflict settings, to encourage combatants to disarm, demobilize, and reintegrate. Over the past two decades, international law has gradually imposed restrictions on applying amnesties to perpetrators of genocide, war crimes, and crimes against humanity. Since 2004, the United Nations (UN) has proclaimed that amnesties are impermissible for gross violations of human rights, such as torture, enforced disappearance, extrajudicial executions, and sexual violence. These restrictions primarily highlight conflicts that can arise between states' duties to prosecute international crimes and serious violations and the role of amnesty in preventing prosecutions. Where amnesties' legal effects also extend to preventing civil liability or truth recovery, they can impede states fulfilling their obligations to investigate and provide a remedy for violations. These conflicts between amnesties and states' obligations to investigate, prosecute, and provide reparations arise most forcefully where these obligations are enshrined 
in international treaties. Academic literature reveals there is much less consensus regarding the existence of a customary prohibition on amnesties for international crimes and serious violation due to lack of consistent state practice. Ascertaining the international legal status of amnesties is further complicated by the fact that international courts have only had to grapple with broad, unconditional amnesties for international crimes and there is no international jurisprudence on the legality of conditional amnesties that require perpetrators to participate in processes to deliver peace, truth, accountability, and/or reparations, or which are designed to provide testimony to support selective prosecution strategies. Given the ambiguities that exist in the international legality of amnesties, this article presents literature with a range of viewpoints. Although literature on the duty to prosecute and other human rights obligations is relevant to understanding the status of amnesties under international law, this article focuses on amnesty-specific literature. This article begins by reviewing general texts on amnesties and international law. It then summarizes texts relating to the history of the use of amnesties and the emergence of the anti-impunity norm. The following section works through academic literature exploring legal sources regulating the use of amnesties, before turning in the next section to writings on the exteraterritorial effects of national amnesties. The final section outlines texts on conditional amnesties and non-judicial remedies.

\section{General Overviews}

Traditionally, the use of amnesties was viewed primarily as a matter of domestic law and policy. At the international level, they regularly featured in agreements to end inter-state armed conflicts, but their use in such settings was subject to negotiations between states rather than international legal regulation. As noted in the *Introduction*, over the past two decades, the development of the duty to prosecute in international criminal law and international human rights law has made it increasingly common to argue that international law now restricts the use of certain forms of amnesty. However, such observations are often succinctly made in scholarly literature and policy papers, and there have been very few texts that have sought to provide detailed analysis of the evidence relating to the legality of amnesties under international law. This section focuses on general overview texts that have sought to answer the question of whether and when amnesties are legal under international law.

\section{Monographs}

Only four monographs have been written on the legality of amnesties under international law, and at the time of writing, almost a decade has passed since the last one was published. Of these books, it is striking that three of them - O'Shea 2002, Mallinder 2008, and Freeman 2009 - find that certain forms of amnesties for international crimes may be permissible under international law, whereas only Chigara 2004 argues that they are impermissible. Mallinder's and Freeman's analyses are drawn from systematic explorations of state practice in relation to amnesties, which led both authors to conclude that there is insufficient evidence to support a customary prohibition on amnesties. 
Chigara, B., Amnesty in International Law: The Legality under International Law of National Amnesty Laws, London: Longman, 2002.

This dated analysis takes a three-pronged approach to exploring amnesties with respect to treaty and customary international law; human rights are property rights; and state practice of acquiescing with some amnesties, while challenging others. It concludes by outlining a model for distinguishing sustainable amnesties from those that are unsustainable that rests predominantly on the argument that any amnesty that prevents criminal or civil liability for human rights violations is impermissible.

Freeman, M. Necessary Evils: Amnesties and the Search for Justice. New York: Cambridge University Press, 2009

This excellent monograph provides a detailed and carefully reasoned evaluation of international law and policy on amnesties for international crimes. Its analysis draws on an extensive overview of state practice and it seeks to reframe global debate on the legality of amnesties by arguing that amnesties are sometimes defensible and legal in the aftermath of mass violence.

Mallinder, L., Amnesty, Human Rights, and Political Transitions: Bridging the Peace and Justice Divide. Oxford: Hart Publishing, 2008.

Draws on the Amnesty Law Database containing information on 506 amnesty processes in 130 countries since 1946. The data is used to identify patterns in when, why and how amnesties are used. The author finds considerable disparity in the practice of states introducing amnesties or responding to amnesties in third states and concludes that there is little evidence that states are moving away from using amnesties for international crimes.

O'Shea, A., Amnesty for Crime in International Law and Practice. The Hague: Kluwer Law International, 2002.

The central purpose of this book is to reconcile what the author views as the utility of amnesties at the national level with the developing principles of international law. The solution proposed is a Protocol to the Rome Statute of the International Criminal Court that would set out principles governing the use of amnesties.

\section{Articles, Book Chapters, and Guidelines}

Articles on the legality of amnesties under international law began to appear during the early 1990s. Given that there have been substantial developments since that point, this section focuses on more recent journal articles, book chapters, and guidelines on the use of amnesties. This literature reflects divergent opinions within academia and practice regarding the legality of amnesties with Laplante 2009, Sadat 2005, and Ludwin-King 2009 finding that an international law norm had emerged or was emerging to prohibit amnesties for international crimes (Laplante argues that this also applies to gross human rights violations). 
In contrast, **Belfast Guidelines on Amnesty and Accountability**, Hadden 2017, Schabas 2012, Slye 2002, and Trumbull 2007 find that there is insufficient evidence to support the existence of such a norm and hence argue that international law continues to allow states flexibility in the design of amnesties.

Belfast Guidelines on Amnesty and Accountability. Jordanstown, Northern Ireland: Transitional Justice Institute, 2013.

The Belfast Guidelines, collectively authored by an expert group, argue that amnesties' legality should be considered in relation to states' duties to prevent, investigate, prosecute, punish, and provide remedies and that the duty to prosecute cannot trump other obligations. They also assert there is insufficient evidence to support the existence of an established, explicit, and categorical customary prohibition of amnesties for international crimes.

Hadden, T., "Transitional Justice and Amnesties." In: C. Lawther, L. Moffett, and D. Jacobs (eds), Research Handbook on Transitional Justice. Cheltenham: Edward Elgar Publishing, 2017, pp. 358-376.

This chapter draws on the Belfast Guidelines on Amnesty and Accountability to argue states have multiple obligations under international law and practice, including the duties to prevent, investigate, prosecute, and provide reparations. The chapter contends that it is unhelpful to privilege the duty to prosecute over states' other obligations and that instead, states should harmonize their fulfilment of these obligations, which may allow for carefully designed amnesties.

Laplante, L.J., "Outlawing Amnesty: The Return of Criminal Justice in Transitional Justice Schemes." Virginia Journal of International Law 49 (2009): 915-984.

Seeks to merge the fields of international criminal law and international human rights law to argue that prohibitions of amnesties for international crimes should also extend to amnesties for gross human rights violations. The approach is interesting and well-reasoned but relies heavily on Latin American experiences of amnesties and on the Inter-American Court's Barrios Altos case. It does not consider whether the Inter-American Court's approach is universally accepted.

Ludwin-King, E.B., "Amnesties in a Time of Transition." George Washington International Law Review 41 (2009): 577-618

Argues based on a doctrinal analysis that there is no international consensus on the permissibility of amnesties under international law. It then uses primarily "soft law" standards to argue that a new customary international law norm was emerging that prohibits "blanket amnesties" and holds that amnesties are permissible only where they are necessary to end conflict, equal in application, and narrowly tailored to a particular context.

Sadat, L.N., "Exile, Amnesty and International Law." Notre Dame Law Review 81 (2005): 955-1036. 
Examines state and international practice on amnesties for international crimes, including national and international case law. It argues that a norm prohibiting amnesties was "strengthening". It further refutes arguments that amnesty can be granted in exchange for peace and contends that amnesties may entrench cultures of violence.

Schabas, W.B., "No Peace Without Justice? The Amnesty Quandary." In: Unimaginable Atrocities: Justice, Politics and Rights at the War Crimes Tribunals. Oxford: Oxford University Press, 2012.

Provides an engaging and critical analysis of the origins of claims for the existence of an international law prohibition on amnesties, including a careful debunking of assertions that Article 6(5) of Additional Protocol II to the Geneva Conventions should be reinterpreted based on the treaty's travaux préparatoires. It argues for the adoption of approaches that balance the need for amnesty to ensure peace with victims' right to justice.

Slye, R.C., "The Legitimacy of Amnesties under International Law and General Principles of Anglo-American Law: Is a Legitimate Amnesty Possible?" Virginia Journal of International Law 43 (2002): 173-247.

Evaluates the legitimacy of amnesty with respect to the duty to prosecute, the fundamental rights of victims, social stability, as well as six general principles of law. Argues that international law restricts the use of amnesties but it remains possible to design legal amnesties for gross human rights violations based on the principles of accountability, truth, reparations, and participation.

Trumbull, C.P., "Giving Amnesties a Second Chance." Berkeley Journal of International Law, 25 (2007): 283345.

Reviews treaty obligations and state practice to argue that customary international law does not contain a general duty to prosecute the most serious crimes, and that consequently, there is no customary prohibition on amnesties. The careful analysis of customary international law considers states' refusal to prohibit amnesties in treaties, UN engagement with amnesties, state practice in granting amnesty, and the practice of third states negotiating or supporting amnesties.

\section{History of the Use of Amnesties and the Growth of the Anti-Impunity Campaign}

The use of amnesties can be traced back to the earliest written legal texts. For example, the Kadesh Peace Agreement of 1269 BCE, enacted to end armed conflict between ancient Egypt and the Hittites, committed both parties to repatriate persons who sought to defect from their home countries and to refrain from imposing punishments on persons who are repatriated. In addition, as Carawan 2013 explores, amnesties were used in ancient Athens in 403 BCE to end a civil war. Over the centuries, as illustrated by Domb 1995, amnesties were frequently used to resolve armed conflicts between states. There are also numerous examples of historical amnesties to end civil wars or ease domestic unrest. It is therefore surprising that no history of amnesties has been published at the time of writing, although Close will address this gap. The 
sources in this section indicate that the few writings that do exist are piecemeal in their accounts, focusing on the historical use of particular types of amnesties (such as amnesties to resolve conflict as discussed by Domb 1995); amnesties in particular countries (such as Wiseman 1972's account of amnesties in the United States); or UN practice on amnesty (Stahn 2001). Furthermore, in many of these publications, the history of amnesties is dealt with as a brief context-setting section as part of a broader paper and most accounts are drawn solely from the use of amnesties in what is now termed the Global North. Many of these historical overviews are also dated. Engle 2015 is an exception as the author charts the rise of the anti-impunity norm from the early 1990s and in so doing, explores how approaches to amnesty in international law and policy have shifted over the last three decades. In addition, Jeffery 2014 provides a relatively recent analysis of patterns in the use of amnesties that seeks to explain why they continue to be enacted. Mallinder 2008 (cited under *General Overviews*) is also a useful resource on patterns in the use of amnesty since 1945.

Carawan, E., The Athenian Amnesty and Reconstructing the Law. Oxford: Oxford University Press, 2013.

This monograph evaluates the contribution of amnesty in ancient Athens to peace, reconciliation, and the reconstruction of laws and democracy. Also explores the conditional nature of the amnesty and how its terms were shaped by criminal trials during its implementation. In doing so, it explores parallels between the Athenian amnesty and more recent forms of conditional amnesty, such as the amnesty granted by the South African Truth and Reconciliation Commission.

Close, J., Amnesties, Serious Crimes and International Law: Global Perspectives in Theory and Practice, Abingdon: Routledge, 2019 [ISBN 978-0-8153-8579-0]

This book provides an historical overview of the use of amnesties for serious crimes, which it charts against the move towards a global accountability norm. This historical analysis is used to test claims regarding the existence of a general amnesty prohibition and in particular, detailed consideration is given to the travaux préparatoires underpinning Article 6(5) of Additional Protocol II to the Geneva Conventions.

Domb. F., "Treatment of War Crimes in Peace Settlements - Prosecution or Amnesty?" In: Y. Dinstein and F. Domb (eds), Israeli Yearbook of International Law. The Hague: Martinus Nijhoff Publishers, 1995, 253-268. Part II of this chapter summarizes the use of amnesty in major peace agreements following international armed conflicts up to end the end of the First World War and it contrasts these practices with the retributive turn taken by the victorious Allied states after the Second World War.

Engle, K., "Anti-Impunity and the Turn to Criminal Law in Human Rights." Cornel/ Law Review 100 (2015): 1069-1127.

This article charts the rise of the anti-impunity norm through an analysis of international human rights law jurisprudence and scholarly writings. It argues that amnesty jurisprudence from the Inter-American 
human rights system has guided a turn to criminal law within human rights. This analysis is not a history of amnesties per se but is useful to understand how they have become controversial in international law.

Jeffery, R., Amnesties, Accountability and Human Rights. Philadelphia: University of Pennsylvania Press, 2014.

This political science monograph focuses on explaining why amnesties are used. It is useful for scholars interested in state practice as it presents evidence relating to the use of amnesties since the early 1970s.

Joinet, L., Study on Amnesty Laws and their role in the safeguard and protection of human rights, SubCommission on the Prevention of Discrimination and Protection of Minorities (United Nations Economic and Social Council 21 June 1985) E/CN.4/Sub.2/1985/16.

This landmark report produced by an independent expert for the UN Sub-Commission on the Prevention of Discrimination and Protection of Minorities provided the first comparative study of amnesty laws. It explored the positive role that amnesties can play in protecting and promoting human rights. In the years since this report was published, the UN's role has changed markedly.

Stahn, C., "United Nations Peace-Building, Amnesties and Alternative Forms of Justice: A Change in Practice?" International Review of the Red Cross 84 (2002): 191-205.

Charts how approaches to amnesty in UN peacebuilding activities evolved from encouraging transitional states to enact amnesties to facilitate national reconciliation to the position that international law and UN policy precludes UN mediators from endorsing amnesties for international crimes. Demonstrates this shift by referring to multiple transitional countries and UN policy documents. Stahn argues the change was driven by parallel developments in international criminal law.

Wiseman, N., "A History and Discussion of Amnesty." Columbia Human Rights Law Review 4 (1972): 529 540.

The article was written to advocate for amnesty in the United States for deserters and drafter evaders from the Vietnam War. It reviews amnesties granted in the United States since independence to make the case that US leaders have the power to grant amnesty, that there was a tradition of doing so, and that such amnesties had been effective in helping American society to overcome internal discord.

\section{Sources Regulating the Use of Amnesty}

It is common practice for UN policy documents and human rights non-governmental organizations' reports to assert succinctly that amnesties are prohibited for international crimes and gross human rights violations (OHCHR 2009). As Bell 2009 makes clear, such assertions are implicitly based on reading distinct 
sources of international law together into a unified narrative to suggest that international law regulating amnesties is consistent across international humanitarian law, international human rights law, and international criminal law. This approach relies on treaty-based prosecution obligations and on assertions of the emergence or existence of a customary international law rule prohibiting amnesties for international crimes and gross violations of human rights. However, assertions of a uniform prohibition obscure differences in the obligations arising for states from international crimes and gross violations of human rights. For this reason, the different sources of international law on amnesties are handled separately in this article.

Bell, C., On the Law of Peace: Peace Agreements and the Lex Pacificatoria. Oxford: Oxford University Press, 2008.

Chapter 12 argues that peace agreement practice and international law developments prompted a "new law of transitional justice." It argues this new law is drawn from a unified reading of human rights law, humanitarian law, international criminal law, and ordinary criminal law. Argues that the new law permits amnesty to release detainees and encourage combatants to disarm, but precludes "blanket" amnesties, and seeks to balance accountability and conflict resolution.

Office of the High Commissioner of Human Rights, Rule of Law Tools for Post-Conflict States: Amnesties, Geneva: United Nations, 2009.

This report sets out the UN's position that amnesties that prevent prosecutions for war crimes, genocide, crimes against humanity, and other gross violations of human rights are inconsistent with states' obligations under international law as well as with UN policy. It analyses only evidence supportive of this position including treaty-based prosecution obligations, the Rome Statute, the determinations of human rights treaty monitoring bodies, and UN soft law standards.

\section{Treaty-Based Prosecution Obligations}

No international treaty prohibits the use of amnesties. Indeed, as Freeman 2009 (cited under *Monographs*) and Schabas 2012 (cited under *Articles, Book Chapters, and Guidelines*) highlight, when prohibitions on amnesties were proposed in negotiations on the Rome Statute of the International Criminal Court and the International Convention on Enforced Disappearance, they proved highly divisive among the negotiating parties and were dropped. However, treaty-based obligations to prosecute and punish international crimes are routinely cited as evidence that amnesties for international crimes are impermissible as they would prevent a state complying with these obligations. These prosecution obligations can be found in the Geneva Conventions, the Genocide Convention, the Convention Against Torture, and the International Convention on Enforced Disappearance. Freeman 2009 highlights that the prosecution obligations arising from treaties are bound by standard rules of treaty law relating to state consent and non-retrospectivity, meaning the obligations are only binding on states from the time they 
become parties to the treaty. This observation has less relevance for the Geneva Conventions and the Genocide Convention as both long-standing treaties enjoy universal ratification; however, these restrictions are more salient for the more recent conventions against torture and enforced disappearances.

Furthermore, as Cassese and Gaeta 2013 notes, even among the small number of treaties requiring states parties to prosecute and punish specific crimes, different formulations of the nature of state's obligations are used. However, divergent views exist in the literature regarding how much significance should be attributed to these different formulations with respect to amnesties. The **Belfast Guidelines on Amnesty and Accountability** (cited under *Articles, Book Chapters, and Guidelines*) observe that the torture convention (and enforced disappearance conventions which uses similar wording) does not create an obligation to prosecute, but rather only to submit a case to national prosecuting authorities who can decide whether to prosecute according to domestic legal procedures for serious crimes. The **Belfast

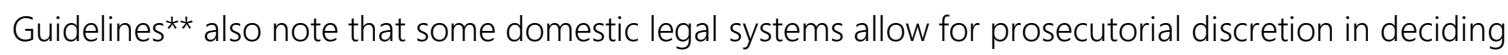
whether to proceed with prosecutions, even for serious offences. This level of flexibility in the duty to prosecute was interpreted as suggesting that amnesties may not automatically violate states' obligations under these conventions. Scharf 1996 takes an opposing view.

Cassese, A. and Gaeta, P., Cassese's International Criminal Law. 3rd ed, Oxford: Oxford University Press, 2013.

Argues that the scope and purpose of treaty obligations to prosecute international crimes vary, and the Convention against Torture allows prosecuting authorities to exercise discretion, at least in extraterritorial proceedings. But argues that where amnesties conflict with treaty-based prosecution obligations, they are impermissible.

Scharf, M.P, "The Letter of the Law: The Scope of the International Legal Obligation to Prosecute Human Rights Crimes." Law and Contemporary Problems 59 (1996): 41-61.

This now quite dated article explores when negotiators can offer amnesties to end violence. Its enduring value comes in its careful unpacking of the different legal sources regulating the use of amnesties, including treaties, customary international law, and UN Security Council resolutions. It compares the language used in treaty-based prosecution obligations but argues that the formulation used in the Convention against Torture should not be construed as permitting amnesty.

\section{Customary International Law}

The status of amnesties under customary international law is central to assertions of a uniform prohibition on amnesties under international law because where treaty rules contain gaps or are non-existent, customary international law may fill those gaps. This is particularly significant for crimes against humanity and war crimes other than grave breaches of the Geneva Conventions and Additional Protocol I, because these crimes are primarily subject to customary international law. However, given that no treaty explicitly prohibits amnesties, customary international law is also used to bolster arguments that where an amnesty 
comes into conflict with treaty-based prosecution obligations, it is impermissible. These arguments often center on assertions that the treaty-based prosecution obligations have become jus cogens norms that take precedence over conflicting obligations. In addition, whereas treaty law is binding only on states parties to the relevant treaties (and may be subject to reservations, declarations and derogations), customary international law is binding on all states. As the legality of amnesties under customary international is covered in many of the *General Overview* pieces, this section will focus on amnesties for crimes against humanity and war crimes in non-international armed conflicts. None of these sources argues for the existence of a broad customary rule prohibiting amnesty for international crimes. The absence of such a rule was also asserted by Cassese and Gaeta 2013 (cited under *Treaty-Based Prosecution Obligations*) and Meisenberg 2004. However, Henckaerts and Doswold-Beck 2005 uses an analysis of customary international law to argue that amnesties cannot be granted to war crimes committed in international or internal armed conflicts. Ntoubandi 2007 finds that amnesties cannot be granted for crimes against humanity, although this position is not based on an analysis of customary international law.

Henckaerts, J.M. and Doswald-Beck, L., Customary International Humanitarian Law, Vols 1-2, International Committee of the Red Cross and Cambridge University Press, 2005.

This monograph draws on an extensive study of state practice to present new rules of customary international law. For amnesties, the authors call for Article 6(5) of Additional Protocol II to Geneva Conventions to be reinterpreted to preclude amnesties for war crimes following civil wars. To support their argument, the authors rely on the travaux préparatoires and a small selection of state practice, not all of which supports the claim being made.

Meisenberg, S.M., "Legality of Amnesties in International Humanitarian Law: The Lomé Amnesty Decision of the Special Court for Sierra Leone." International Review of the Red Cross 86 (2004) 837-851.

This article critiques the 2004 Lomé Amnesty decision by the Special Court of Sierra Leone. The decision is notable as it is the first to argue that a customary rule prohibiting amnesties for international crimes was emerging. Meisenberg contends that the significance of these comments are questionable as they are in obiter and the Court failed to present adequate evidence to support its conclusions.

Ntoubandi, F.Z., Amnesty for Crimes Against Humanity Under International Law, The Hague: Martinus Nijhoff Publishers, 2007.

Argues that while written international law requires prosecution of international crimes, state practice tends towards political solutions. It does not review state practice. However, it argues that international criminal liability for crimes against humanity is entrenched and that consequently no amnesty is permitted for these crimes. This is at odds with the author's observation that customary international law creates only a permissive duty to prosecute crimes against humanity. 


\section{International Human Rights Law}

Amnesties are not explicitly mentioned in the comprehensive human rights treaties. Neither do these treaties explicitly require states to prosecute and punish violations of the rights they protect. Instead, regional human rights courts and other treaty-monitoring bodies have read "positive obligations" to investigate, prosecute, and punish gross human rights violations into human rights conventions. Based on the obligations that they have read into the Conventions, these institutions have then inferred that certain forms of amnesty are impermissible for gross violations of human rights. The Inter-American human rights system has produced the most detailed amnesty case law as a result of the prevalent use of amnesties in South America to deal with crimes related to the region's military dictatorships. These judgments find that amnesties that prevent investigation and prosecution of international crimes, such as war crimes, crimes against humanity, and torture, as well as serious human rights violations of extrajudicial executions and enforced disappearances are impermissible. In contrast, the European Court of Human Rights has not thus far been asked to rule directly on an amnesty for international crimes. However, in a small number of cases, it has offered general comments on amnesty, which indicate that in general, the European Court views amnesties for international crimes as impermissible; but the Court continues to maintain that states are permitted to amnesty violations of the right to life, except in instances of widespread killings of civilians by state officials. The African Court of Human and People's Rights has yet to give detailed consideration to the legality of amnesties. The UN treaty monitoring bodies, particularly the UN Human Rights Committee, have also developed an extensive body of non-binding opinions that reject the use of amnesties for nonderogable human rights violations. The legal status of amnesties under international human rights law has received less academic scrutiny than their status under international criminal law. The texts that do exist often focus on a particular human rights system such as Mallinder 2016, Laplante 2009 (cited under *Articles, Book Chapters, and Guidelines*), and Binder 2011 on the Inter-American system, or Mallinder et al 2015 on the European human rights system). Other works, like Seibert-Fohr 2009 and Vriezen 2012, are comparative analyses of the positions adopted by the various human rights systems.

Binder, C., "The Prohibition of Amnesties by the Inter-American Court of Human Rights." German Law Journa/12 (2011) 1203-1229.

Examines the Inter-American Court of Human Rights' amnesty jurisprudence and argues that the Court has considerably expanded its powers beyond what was originally envisaged in the American Convention on Human Rights. The Court has particularly done this by developing the conventionality control, which it uses to order states to annul amnesty laws that violate the Convention. Indicates problems that arise from the Court's overly broad interpretation of its own powers.

Mallinder, L., "The End of Amnesty or Regional Overreach? Interpreting the Erosion of South America's Amnesty Laws." International and Comparative Law Quarterly 65 (2016) 645-680. 
Draws on a comparative analysis of the case law of the Inter-American Court of Human Rights and national courts to explore the parameters of the regional trend in South America to move way from broad, unconditional amnesties in transitions from dictatorship. It argues that in transitions from armed conflict, the regional trend continues to allow certain forms of leniency when balancing peace against justice.

Mallinder, L., Moffett, L., McEvoy, K. and Anthony, G., Investigations, Prosecutions and Amnesties under Articles 2 \& 3 of the European Convention on Human Rights. Belfast: Queen's University Belfast, 2015. [ISBN: 9781909131323$]$

Draws on the European Court of Human Rights' general comments on amnesties and its case law on Articles 2 and 3's procedural obligations to argue that Court is likely to subject amnesties that prevent prosecutions for international crimes to greater scrutiny than amnesties that cover only Convention violations. Also argues that the Court may accept amnesties for the most serious offences if part of reconciliation processes.

Seibert-Fohr, A., Prosecuting Serious Human Rights Violations. Oxford: Oxford University Press, 2009. This excellent book analyses the case law of the Inter-American, European, and UN human rights systems to ascertain the parameters of the duty to prosecute. In so doing, it considers the implications of amnesties on the fulfilment of states' obligations to investigate, prosecute, and provide reparations for harms. It also considers the approach of each institution to balancing reconciliation and justice.

Vriezen, V., Amnesty Justified? The Need for a Case by Case Approach in the Interests of Human Rights. Antwerp: Intersentia, 2012.

This monograph provides a sweeping overview of the pronouncements on amnesty of the UN Human Rights Committee and other UN human rights monitoring bodies, the Inter-American human rights organs, the European Court of Human Rights, international criminal tribunals, and national courts acting under the principle of universal jurisdiction. However, its handling of each of these issues is rather brief.

\section{The Extraterritorial Effects of National Amnesties for International Crimes}

The academic literature on the extraterritorial effects of national amnesties has three main themes. Firstly, the case law of the hybrid courts and the International Criminal Tribunal for the Former Yugoslavia arguing that national amnesties cannot bar these tribunals from exercising jurisdiction over crimes covered by their statutes. Secondly, literature exploring the status of the amnesties under the Rome Statute of the International Criminal Court. And thirdly, a very limited literature on the effect of amnesties on prosecutions in foreign states under extraterritorial principles of jurisdiction, including universal jurisdiction. This section explores each theme in turn. 
Amnesties in the Case Law of the Hybrid Courts and the International Criminal Tribunal for the Former Yugoslavia

Amnesties are generally enacted at the national level to bind the actions of national courts. National amnesties do not automatically prevent international courts from trying persons who have previously benefited from an amnesty. As a result, a limited case law has developed where individuals who have benefited from an amnesty before becoming subject to criminal proceedings at an international or hybrid court have invoked the amnesty to argue that the court has no jurisdiction, and that to prosecute would be an abuse of process. These cases all related to unconditional amnesties for international crimes. In all instances, the Courts found that they were not bound to recognize a national amnesty. Some hybrid courts relied on provisions in their statutes that stated that pre-existing amnesties cannot bar prosecution of persons falling within the jurisdiction of the court. The amnesty decisions of the Special Court of Sierra Leone have been given the greatest scrutiny in the literature, as this was the first international criminal court to tackle amnesties in a series of four decisions. However, as Cassese 2004, Meisenberg 2004, Williams 2005, and Schabas 2004 indicate, the legal reasoning in these decisions was problematic in the lines of reasoning that were pursued and the paucity of supporting evidence. The ICTY has also considered amnesty in the Furundzija case, in which it made obiter comments that a hypothetical amnesty for war crimes would be impermissible. No articles have been published exclusively on this case but it is discussed in Meisenberg 2004, Brockman-Hawe 2009, and Naqvi 2003 (cited under *Amnesties and Prosecutions in Third States*) as well as Freeman 2009 (cited under *Monographs*). Secondly, in the Karadzic case, the ICTY considered Karadzic's allegation that he had been offered a secret immunity deal by US negotiator Richard Holbrooke in exchange for withdrawing from public life. Brockman-Hawe 2009 critiques at length the resulting trial chamber decision and Ventura 2009 discusses the Appeal Chamber's brief pronouncement on the same issue. Both works find the Court's approach underdeveloped and problematic. The most carefully reasoned approach to the status of amnesties under international law was conducted by the Extraordinary Chambers of the Courts of Cambodia in the leng Sary case. However, these components of the decision have yet to be fully explored in academic literature. Slye 2012 is useful for providing an overview of the facts of the case and an analysis of other points of the judgment.

Brockman-Hawe, B., "International Criminal Tribunal for the Former Yugoslavia Decision on the Accused's Second Motion for Inspection and Disclosure: Immunity Issue Trial Chamber Decision of 17 December 2008." International and Comparative Law Quarterly 58 (2009) 726-740.

Summarizes and critiques the 2008 decision of the ICTY Trial Chamber on Karadzic's allegation that he was offered immunity from prosecution. Highly critical of the Chamber's reasoning which is described as "undeveloped, unsatisfying and unpersuasive". Highlights in particular the Chamber's failure to consider state practice.

Cassese, A., "The Special Court and International Law - The Decision Concerning the Leone Agreement Amnesty." Journal of International Criminal Justice 2 (2004): 1130-1140. 
Reviews the reasoning of the Special Court of Sierra Leone in the Lomé Amnesty Case. Characterizes the reasoning as "flawed" due to convoluted and contradictory arguments and insufficient supporting evidence. Presents alternative reasoning before arguing that the jus cogens character of international rules prohibiting and criminalizing international crimes means that international courts are not bound by national amnesties.

Meisenberg, S.M., "Legality of amnesties in international humanitarian law. The Lomé Amnesty Decision of the Special Court for Sierra Leone." International Review of the Red Cross 86 (2004): 837-851.

Contends that the Court's obiter dicta pronouncement on amnesty in the Lomé Amnesty Decision significance in international law is weakened by poor judicial reasoning. In particular, contends that the Court was incorrect to base its decision on the universality principle and it did not provide evidence to support its conclusions. In addition, argues that the Court should have grappled with the amnesty being conditional with compliance with the peace agreement.

Schabas, W.A., "Amnesty, the Sierra Leone Truth and Reconciliation Commission and the Special Court for Sierra Leone." UC Davis Journal of International Law and Policy 11 (2004): 145-169.

Contrasts the positions taken by the Sierra Leone Truth and Reconciliation Commission (TRC) and the Special Court of Sierra Leone to the Lomé amnesty. Unlike the Court, the TRC took a practical approach considering the role of amnesties in conflict resolution. Schabas argues that the Court's finding that a customary prohibition on amnesties was emerging is unhelpful, went beyond existing law, and limited possibilities for balancing peace and justice.

Williams, S., "Amnesties in International Law: The Experience of the Special Court for Sierra Leone." Human Rights Law Review 5 (2005): 271-309.

Examines four decisions of the Special Court of Sierra Leone on amnesties and evaluates the reasoning in light of international standards. Contrasts the reasoning of the court with a separate opinion of Justice Robertson and finds that the Court's reasoning was problematic and failed to take into account state practice and other relevant evidence, and also failed to consider the conditional nature of the Lomé amnesty.

Ventura, M., "The Prosecutor v. Radovan Karadzic: The Indictment, English Language and Holbrooke Agreement Decisions". Australian Journal of International Law 16 (2009):

Analyses the ICTY Appeals Chamber decision on Karadzic's claim that US negotiator Holbrooke offered him immunity. Decision referred to the existence of an international rule that would prevent those accused of international crimes from benefiting from amnesty or immunity, but Ventura argues it "did not assist legal debate surrounding amnesties and immunities" as there was insufficient elaboration or evidence was provided to support the pronouncement. 
Slye, R., "A Limited Amnesty? Insights from Cambodia." In: F. Lessa and L. Payne (eds), Amnesty in the Age of Human Rights Accountability: Comparative and International Perspectives. New York: Cambridge, 2012, 291-314.

Uses the Cambodian 1994 amnesty to explore issues relating to who should benefit from an amnesty and how long an amnesty should last. The chapter discussed the leng Sary case with respect to how the ECCC's decision shaped who could benefit from the 1994 amnesty for members of the Khmer Rouge. Chapter is a useful resource for discussions of limited or temporary amnesty.

\section{Amnesties and the International Criminal Court}

The Rome Statute of the International Criminal Court is silent on the question of amnesties and the Court has yet to make any decisions on amnesties. In this vacuum, scholars including Gavron 2002, Scharf 1999, El Zeidy 2002, Stahn 2005, and Robinson 2003 have sought to speculate on the circumstances in which the Court might recognize some forms of national amnesty largely through reviewing the provisions of the Rome Statute that seemingly allow the Court discretion in deciding whether to proceed. Similar analysis has been conducted by Mallinder 2008, Freeman 2009, and Schabas 2012 (cited under *general overview*). Most of this literature finds that in exceptional circumstances, the Court may have discretion to recognize certain forms of amnesty, usually those that are more limited and conditional.

El Zeidy, M.M., "The Principle of Complementarity: A New Machinery to Implement International Criminal Law." Michigan Journal of International Law23 (2002): 869-976.

Section IV of this article argues that the Rome Statute left room for states to grant amnesties for international crimes and that it provides the court with tools to distinguish between good and bad amnesties. The latter are characterized as unconditional amnesties granted before the crimes are investigated. Argues, however, that this flexibility is problematic and the Court should reject all amnesties for international crimes.

Gavron, J., "Amnesties in the Light of Developments in International Law and the Establishment of the International Criminal Court." International and Comparative Law Quarterly 51 (2002) 91-117.

Begins with an overview of the evolution in international law standards on amnesty. Then focuses on the ICC, which was newly created, at the time this piece was published, describing the contestations over amnesties in the negotiations to create the Court and then reviewing the provisions of the Rome Statute that may allow the Court to recognize amnesties. Argues the court will have a strong presumption against amnesties but may recognize them in limited circumstances.

Robinson, D., "Serving the Interests of Justice: Amnesties, Truth Commissions and the International Criminal Court." European Journal of International Law 14 (2003): 481-505. 
Analyses the provisions of the Rome Statute that might allow the Court to recognize national amnesties granted as part of broader reconciliation processes. Argues that in exceptional circumstances, a rigid approach to prosecutions by the ICC might be irresponsible and sets out guidance to support the Court in making case-by-case determinations on the permissibility of limited and conditional amnesties. Finds blanket amnesties for most responsible are always unacceptable.

Scharf, M.P., "The Amnesty Exception to the Jurisdiction of the International Criminal Court." Cornell International Law Journa/32 (1999) 507-527.

Uses case studies on the role that amnesty plays in peace settlements and argues that amnesties are not equivalent to impunity. Then reviews the "limited" duty to prosecute, before describing Rome Statute provisions that could allow the court to recognize a national amnesty. Argues that there is sufficient flexibility in the Statute to ensure that amnesties can continue as a viable "bargaining chip" for mediators trying to end armed conflict.

Stahn, C., "Complementarity, Amnesties and Alternative Forms of Justice: Some Interpretative Guidelines for the International Criminal Court." Journal of International Criminal Justice 3 (2005): 695-720.

Argues that the ICC Statute leaves the Court discretion in determining whether a national amnesty could bar prosecution. Suggests guidelines to inform such determinations including that amnesties for ICC crimes should generally be considered incompatible with the Statute and that exceptions should only arise in exceptional cases where the amnesty is conditional and accompanied by alternative forms of justice.

\section{Amnesties and Prosecutions in Third States}

In the aftermath of the arrest and home detention of former Chilean dictator Augusto Pinochet in London in 1998-1999, there was considerable global optimism about the possibilities of universal jurisdiction to tackle impunity. This fed into discussions of amnesties with works such as Boed 2000, Meintjes and Méndez 2000, Naqvi 2003 and Sadat 2003 arguing that courts in third states acting under the principle of universal jurisdiction were not bound by national amnesties. These works then presented various guidelines to inform decisions in foreign courts on whether to respect national amnesties. Their analyses mostly argued that unconditional amnesties for the most serious offenders should not be respected whereas foreign courts had more scope to respect conditional amnesties. In the years since, several states with previously generous universal jurisdiction provisions in their national criminal code have narrowed them, resulting in what some have termed the decline of universal jurisdiction. It is therefore unsurprising that the relationship of amnesties to universal jurisdiction has received less scrutiny in recent years. However, as Roht-Arriaza 2007 argues, the Spanish universal jurisdiction cases relating to human rights abuses in South America contributed to the erosion of amnesties in that region. 
Boed, R., "The Effect of a Domestic Amnesty on the Ability of Foreign States to Prosecute Alleged Perpetrators of Serious Human Rights Violations." Cornell International Law Journa/33 (2000): 297-329.

Develops a framework for determining when states with no connection to an offence may prosecute the alleged offender who has been amnestied in the country where the offence took place. Outlines two-part test: whether the offences are subject to universal jurisdiction; and whether the amnesty is valid under international law. Argues that if international law requires the offences be prosecuted, amnesty cannot bar the foreign state exercising jurisdiction.

Meintjes, G. and Méndez, J., "Reconciling Amnesties with Universal Jurisdiction" International Law FORUM du droit internationa/2 (2000): 76-97.

Argues that states can no longer expect international deference to domestic amnesty arrangements and asserts that unconditional or self-amnesties will not be respected by the international community. Uses the South African amnesty for truth model as a possible framework for international actors to inform decisions on whether to respect national amnesties. Article triggered a debate in the journal regarding whether the South African amnesty complied with international law.

Naqvi, Y., "Amnesty for War Crimes: Defining the Limits of International Recognition." International Review of the Red Cross, 85 (2003), pp. 583-624.

Argues that international courts and courts in foreign states are permitted to disregard national amnesties for war crimes, but they do not have an obligation to do so. Uses state practice and international case law to argue that an acceptable amnesty should limited to objectives such as achieving peace, be accompanied by other accountability mechanisms, not be a self-amnesty, and only be available to lower-level offenders.

Roht-Arriaza, N. "The Pinochet Effect and the Spanish Contribution to Universal Jurisdiction." In: W. Kaleck et al (eds), International Prosecution of Human Rights Crimes. Berlin: Springer, 2007, 113-123.

Part 1 of this chapter charts the contribution of Spanish universal jurisdiction cases relating to abuses committed by the ousted military dictatorships in Argentina and Chile to the erosion of the amnesties in those countries.

Sadat, L.N., "Universal Jurisdiction, National Amnesties, and Truth Commissions: Reconciling the Irreconcilable." In: Macedo, S., (ed), Universal Jurisdiction: National Courts and the Prosecution of Serious Crimes Under International Law. Philadelphia: University of Pennsylvania Press, 2003, 193-213.

Argues that foreign states seeking to prosecute offenders for crimes alleged to have been committed elsewhere should treat national amnesties for international crimes as presumptively invalid. But this presumption can be overcome where the amnesty is granted as part of a broader process allowing for accountability. Finds that unconditional blanket amnesties can never bar jurisdiction. 


\section{Conditional Amnesties and Non-Judicial Remedies}

Much of the literature described in the preceding sections argued that flexibility remains in the status of amnesties under international law and set out frameworks to evaluate when amnesties would be permissible. In many cases, these frameworks called for the scope of the amnesty to be carefully evaluated based on the context in which it is introduced, whether it is limited in terms of the crimes or level of responsibility of the offenders; and whether the amnesty was conditional on beneficiaries' contributions to accountability and reconciliation processes. This final section focuses directly on conditional amnesties given their emergence as a central issue in considerations of amnesties' legality and their potential to move discussions of the legality of amnesty beyond focusing solely on the duty to prosecute but also encompass other obligations including the duty to prevent, investigate, and provide reparations (see **Belfast Guidelines on Amnesty and Accountability** in *Articles, Book Chapters, and Guidelines*). Mallinder 2008 and Freeman 2009 provide detailed analyses of the types of conditions that can be attached to amnesties (cited in *General Overview*). The literature reviewed in this section focuses on the extent to which conditional amnesties can be designed to deliver social goods, such as du Bois-Pedain 2011's exploration of the relationship between amnesty and accountability, Mallinder 2014's application of restorative justice theory to amnesties, and Sarkin 2017's analysis of how amnesties can contribute to truth. In addition, Fiddler 2015 looks specifically at the status of legality of conditional amnesties.

Du Bois-Pedain, A., "Post-conflict Accountability and the Demands of Justice: Can Conditional Amnesties take the Place of Criminal Prosecutions?" In: N. Palmer, P. Clark and D. Granville (eds), Critical Perspectives in Transitional Justice. Antwerp: Intersentia, 2011, 459-483.

Evaluates the extent to which the conditional amnesty process implemented by the South African Truth and Reconciliation Commission was able to contribute to accountability. Argues that some features of the amnesty process could meaningfully deliver accountability, but its effectiveness was undermined by the resistance of the South African state to pursue criminal prosecutions for offenders who were refused amnesty or did not apply.

Fiddler, G., "Using a Conditional Amnesty and Truth and Reconciliation Commission as a Transitional Justice Mechanism in Syria." George Washington International Law Review 47 (2015): 893-918.

Part III of this Note highlights that conditional amnesties with truth commissions are not prohibited by codified international law. It further argues that they are not prohibited under customary international law as there is insufficient state practice to support the existence of such a prohibition. She furtherlt also notes argues that there is limited evidence that states are declining to maintain and apply preexisting conditional amnesties. 
Mallinder, L., "Amnesties in the Pursuit of Reconciliation, Restorative Justice and Peacebuilding." In: J. Llewellyn and D. Philpott (eds), Restorative Justice, Reconciliation and Peacebuilding. New York: Oxford University Press, 2014, 138-173.

Drawing on restorative justice theory and the relationships between amnesty and accountability processes in Timor-Leste, South Africa and Uganda, this chapter proposes elements to inform the design of "restorative amnesties." It argues employing this framework and adapting it for local contexts can enable amnesties to facilitate inclusive restorative processes, promote truth recovery, enforce restorative outcomes, and provide reparations.

Sarkin, J.J., "How Conditional Amnesties Can Assist Transitional Societies in Delivering on the Right to the Truth: Are Such Processes Compatible with International Law?" International Human Rights Law Review6 (2017): 143-175.

The article is based on the assumption that conditional amnesties can play a significant role in truth recovery and it contends that without such guarantees, perpetrators are unlikely to participate in truth recovery processes. It further explores the legality of conditional amnesties under international law drawing on state practice. 